August 2012

\title{
Thy Brother's Keeper? The Relationship between Social Distance and Intensity of Dehumanization during Genocide
}

Lisa Haagensen

Marnix Croes

Follow this and additional works at: https://digitalcommons.usf.edu/gsp

\section{Recommended Citation}

Haagensen, Lisa and Croes, Marnix (2012) "Thy Brother's Keeper? The Relationship between Social Distance and Intensity of Dehumanization during Genocide," Genocide Studies and Prevention: An International Journal: Vol. 7: Iss. 2: Article 7.

DOI: $10.3138 /$ gsp.7.2/3.223

Available at: https://digitalcommons.usf.edu/gsp/vol7/iss2/7

This Articles is brought to you for free and open access by the Open Access Journals at Digital Commons @ University of South Florida. It has been accepted for inclusion in Genocide Studies and Prevention: An International Journal by an authorized editor of Digital Commons @ University of South Florida. For more information, please contact digitalcommons@usf.edu. 


\title{
Thy Brother's Keeper? The Relationship between Social Distance and Intensity of Dehumanization during Genocide
}

\author{
Lisa Haagensen ${ }^{1}$ \\ University of Amsterdam \\ Marnix Croes \\ Netherlands Ministry of Safety and Justice
}

This paper puts forth the hypothesis that the degree of social distance between perpetrator and victim groups prior to the outbreak of genocide is inversely related to the degree of severity of dehumanization employed by the perpetrator group during genocide. Derived from psychological theory, this hypothesis is illustrated by using a primarily literature-based method of analysis combined with a vignette-designed severity of dehumanization scale. Three genocides are compared: the Rwandan Genocide, the Holocaust as it occurred in Western Europe, and the Holocaust as it occurred in Eastern Europe. The findings for Rwanda and the Holocaust in Eastern Europe show a negative correlation between the two variables, confirming the hypothesis. The results for Western Europe, however, present somewhat of an anomaly; variations in the extermination policies of the German perpetrators in Eastern and Western Europe correspond to this difference and can, in this case, provide a possible explanation for the incongruity.

Key words: psychology, social distance, perpetrators, victims, barbarity, genocide, Rwanda, Holocaust, dehumanization

\section{Introduction}

In her seminal work on genocide, Helen Fein defines the phenomenon as the "sustained purposeful action by a perpetrator to physically destroy a collective directly or indirectly, through interdiction of the biological and social reproduction of group members, sustained regardless of the surrender or lack of threat offered by the victim."2 Genocide and other forms of mass killing have recurred frequently over the past 50 years. Events in Rwanda and Darfur, for instance, are just two examples of recent genocidal events that have left the international community in shock. ${ }^{3}$ Surprisingly perhaps, the perpetrators of this barbarity are neither extraordinary nor particularly prone to pathology and/or insanity. Rather, perpetrators typically reflect an ordinary distribution of humanity ${ }^{4}$ : some are wealthy while others are impoverished; some are religious and others agnostic; some are relatively young and others relatively old. Most of them are not psychologically impaired nor are they typically the products of abusive childhoods. ${ }^{5}$ In short, the majority of perpetrators of genocide are ordinary people. ${ }^{6}$

This is particularly apparent when examining the Rwandan Genocide, a case where the killers were, to a large extent, not only ordinary civilians but also often personally acquainted with their victims. Even so, they displayed an extraordinary inclination toward brutality. Innocent Rwililiza, a survivor of the Rwandan Genocide, reflects that the cruelty of the slaughter was not executed by "demons or drug-crazed interahamwe"

Lisa Haagensen and Marnix Croes, "Thy Brother's Keeper? The Relationship between Social Distance and Intensity of Dehumanization during Genocide," Genocide Studies and Prevention 7, 2/3 (August/December 2012): 223-250. ๑ 2012 Genocide Studies and Prevention. doi: 10.3138/gsp.7.2/3.223 
(Hutu militias), but rather by "neighbors with whom we used to chat while walking to the market."7 During his interview, Rwililiza poses two important questions: "Why did they chop people up instead of killing them straightaway? ... If there was killing to be done, all that had to be done was kill, but why chop arms and legs?"' As illustrated by the survivor and perpetrator interviews conducted by Jean Hatzfeld, many otherwise ordinary Rwandan did not simply kill their victims. Rather, they inflicted a maximum amount of pain and suffering, often wounding and leaving their Tutsi neighbors to die slow and agonizing deaths. ${ }^{9}$ Considering that the vast majority of perpetrators were neither insane nor drugged, how can one explain the unwarranted mutilation, torture, and suffering they inflicted on their victims? According to Rwililiza, it was their personal acquaintanceships with their victims that became the driving force behind the malice. In his view, mutilation and torture represented the means through which the humanity of the victims was removed and the task of killing made easier. ${ }^{10}$

In this paper we seek to develop the hypothesis that social proximity prior to genocides enhances severity of dehumanization during genocide. In other words, the smaller the social distance between the perpetrator group and the victim group the more severe the dehumanizing behaviors of the perpetrators. To do this we compare the cruelty of the killing methods employed by Rwandan perpetrators during the Rwandan Genocide and German perpetrators during the Holocaust in Eastern and Western Europe. To simplify the task of comparison, Germany is used as a model for Western Europe, while the Baltic states and Poland are used as models for Eastern Europe. Although the perpetrators of the Holocaust were in no way limited to those of German nationality, we have to limit our analysis of the behavior of the perpetrators to German nationals for reasons of conciseness. For the same reason, the victim group is limited to people who were deemed Jewish according to the Nazi definition. ${ }^{11}$ As such, in the case of Western Europe, the perpetrators are Germans while the victims are German Jews. In the case of Eastern Europe, the perpetrators are again limited to Germans while the victims are Polish and Baltic Jews. Finally, in the case of Rwanda, the perpetrator group refers to Hutu perpetrators while the victim group refers to Tutsi victims.

The reasons for which these two cases have been selected are twofold: First, the Rwandan Genocide and the Holocaust represent two of the most widely researched and examined cases of genocide today. Consequently, in each case there exists a wealth of information that can be drawn upon for this study. Second, in order to assess the effects of social distance on dehumanization one requires contexts that are characterized by different degrees of social distance. The Rwandan Genocide and the Holocaust-given that we distinguish between the Holocaust in Eastern Europe and the Holocaust in Western Europe-represent three such cases. The Rwandan Genocide was a "neighborhood genocide" 12 where individuals from the victim and perpetrator groups were personally acquainted with one another. In contrast, the Holocaust in Eastern Europe was a predominantly bureaucratic and military-driven undertaking targeting a diffuse population with whom the German perpetrators were not previously acquainted. ${ }^{13}$ With regard to the Holocaust in Germany, acquaintanceship between the German perpetrators and the Jewish victim group did exist, albeit to a lesser extent than in Rwanda.

\section{Theory}

At first glance, our hypothesis may appear counterintuitive from the perspective that acquaintanceship overcomes social barriers and bridges social gaps-a viewpoint, for instance, that underlies Dutch public policy for preventing segregation in public 
primary schools. ${ }^{14}$ However, psychological theory supports our hypothesis. The argument put forth in this paper begins with the assessment that for most people, hurting another human being is unpleasant. Indeed, "most people find it deeply upsetting to inflict harm, pain or death on another person." 15 Consequently, no matter the extent of prejudice and hate one group may feel for another, reservations against killing fellow human beings are deeply entrenched. If systemic killing involving mass participation is to transpire, the target group's status as human beings-as being part of the same moral universe as the perpetrators-must first be removed. ${ }^{16}$ Through dehumanization, the target group is rendered sub- or non-human in the eyes of the perpetrator group, clearly distinguishing "us" from "them." 17 Ultimately, this is a process of facilitation because killing individuals who have been devalued and excluded from the realm of humanity is easier than killing those who have not. ${ }^{18}$ Restraints against persecution and violence are eliminated and mass killings can then unfold within this context of moral exclusion. ${ }^{19}$ "Anything that is done to someone who is morally excluded is permissible no matter how heinous the action." 20 This makes dehumanization a vital cog in the wheel of mass killing campaigns.

Dehumanization can be viewed from the perpetrator's perspective as well as a victim's, and encompasses both the process whereby others' humanity is denied and the cruelty and suffering that embody that process. ${ }^{21}$ The majority of psychological research tends to focus on dehumanization as a process in which negative imagery campaigns and propaganda are employed to reduce the target group's humanity before genocide. ${ }^{22}$ An extensive vocabulary is frequently employed to assign demeaning and animalisticor non-human-qualities to those comprising the target group. ${ }^{23}$ Cockroach, vermin, and parasite are some of the epithets associated with past cases of genocide. ${ }^{24}$ This type of systematic labeling represents a primary way of stripping the humanity of the target group while simultaneously inciting the perpetrator group against them. ${ }^{25}$

Dehumanization, however, does not only play a role in preparing the ground for genocide; it also drives genocidal campaigns forward, sustaining killing operations over lengths of time. ${ }^{26}$ The very dynamic of mass killing necessitates and intensifies dehumanization, for no matter the extent to which one is labeled cockroach or parasite, exterminating people perceived as vermin is simply not the same as exterminating real vermin. ${ }^{27}$ As a result, those who participate in genocidal massacres will infuse their acts with dehumanizing vocabulary in a further and final attempt to break the bonds that tie human beings together. ${ }^{28}$ Dehumanization is as much a part of the killing operations of genocidal campaigns as it is their preparation.

The actual killing that occurs during genocide is always imbued with a degree of dehumanization; however, the degree of severity of dehumanization can vary. It is our hypothesis that such a variation is somewhat determined by prior social distance. Importantly, it must be acknowledged that degrees of social distance do not translate into degrees of amicability. For instance, small social distance does not necessarily imply fondness for the other group. Dislike can also be a function of small social distance; as Roy Baumeister has so aptly put it, "most people reserve their greatest animosities for people they know well." 29 Nevertheless, it goes without saying that smaller social distances often engender liking, which can be borne from similarity, sexual attraction, or relationships of dependence; ${ }^{30}$ all of these categories presuppose social proximity. Assuming that human bonds need more dehumanization to break when social nearness is characterized by fondness, a more precise phrasing of our hypothesis would state that 
where social relations are more affable prior to genocide, more cruelty during genocide is likely to ensue. However, given that we are not able to measure how friendly social relations are or were-only how close-we have to limit ourselves to the inverse relation between social distance and severity of dehumanization. Furthermore, it is important to stress that our hypothesis is solely concerned with differences in perpetrator behavior during genocide and is not concerned with either why the genocides in question occurred, or with the events leading up to their commencement.

\section{Methods}

\section{Measuring social distance}

To measure the social distance between the perpetrator and victim groups in Rwanda, Eastern Europe, and Western Europe, we employed an adaptation of the Bogardus Social Distance Scale. This scale, named after sociologist Emory S. Bogardus, includes a sequence of between five and seven items or statements that convey greater or lesser intimacy toward members of a particular group. ${ }^{31}$ The scale is both one-dimensional and cumulative. Consequently, an individual or group that asserts a certain degree of intimacy toward another will accept items denoting less intimacy. ${ }^{32}$ As a result, accepting members from a group on the scale of marriage will automatically signify acceptance with regards to the previous scales of friends, work colleagues, and neighbors. Table 1 illustrates the intimacy items or statements that make up the Bogardus Social Distance Scale. ${ }^{33}$

For this study, we have utilized a modified version of the Bogardus Scale. The cumulative nature of the original scale enabled us to limit ourselves to the first four items. This made the task at hand decidedly simpler, as data regarding the first four categories is much easier to come by. Furthermore, the first four items on the limited scale were modified from their original survey question format into four socio-demographic categories of social distance: intermarriage, social interaction, workforce integration, and community integration. ${ }^{34}$ Table 2 presents the limited version of the social distance scale and the associated socio-demographic conditions.

Using the modified scale, we analyzed the literature to determine the social distance between the perpetrator and victim groups in each of the genocides studied.

\section{Measuring Severity of Dehumanization}

Measuring severity of dehumanization entails an in-depth analysis of published personal accounts and testimonies of survivors, bystanders, and perpetrators of the three case studies. There are two justifications for the selection of this literature: First and foremost, in order to obtain accurate depictions of the dehumanization behavior

Table 1 - Bogardus Social Distance Scale

1 Would marry

2 Would have as regular friends

3 Would work beside in an office

$4 \quad$ Would have several families in my neighborhood

5 Would have merely as speaking acquaintances

$6 \quad$ Would live outside my neighborhood

$7 \quad$ Would live outside my country 
Table 2 - Modified Bogardus Social Distance Scale

\section{Social Distance Category}

Would marry

Would have as regular friends

Would work beside in an office

Would have several families in my

neighborhood

\section{Corresponding socio-demographic} condition

Intermarriage

Social Interaction

Workforce Integration

Community Integration

employed, first-hand accounts from those who witnessed and even experienced such events are vital. However, the nature of the topic is particularly sensitive due to its focuses on episodes of extreme trauma and distress. Analyzing published personal accounts and testimonies have represented an unobtrusive means of accessing eyewitness accounts. Simply put, published personal accounts and testimonies have allowed us to capture incidents of dehumanization without having to put those who witnessed these traumatic events through renewed pain or distress during interviews. Furthermore, assessing testimonies from perpetrators, victims, and bystanders has allowed us to gather a variety of depictions stemming from all vantage points; this in itself has limited bias. Second, the wealth of published personal accounts and testimonies of survivors, bystanders, and perpetrators of the Rwandan Genocide and the Holocaust render the conducting of fresh, first-hand interviews unnecessary.

Consequently, in order to determine the degree of dehumanization, we have carefully examined the literature from which we compiled a list of all the dehumanizing behaviors represented in each case study. Any perpetrator behavior that encompassed some degree of humiliation, dehumanization, or the inflicting of some level of painphysical and/or psychological-during the killing operations of genocide was considered to be dehumanizing behavior. Within each of the three lists, the behaviors were subsequently grouped according to five behavior categories: dehumanizing living conditions; psychological dehumanization; physical dehumanization without physical pain; and physical dehumanization with physical pain. The latter was further separated into abuse with the use of instruments and abuse without instruments.

Dehumanizing living conditions concerns living conditions that are unfit for human dwelling and threaten survival. The victim is forced, either directly or indirectly, to endure these conditions for extended periods of time.

Psychological dehumanization concerns perpetrator behaviors that inflict psychological torment, humiliation, and/or dehumanization upon the victim. Behaviors within this category range from derogatory labeling and name-calling, through to threats, taunts, degrading insults, defamation, and slander.

Physical dehumanization without physical pain concerns any humiliating and dehumanizing behavior or action that is either inflicted upon a victim by a perpetrator, or that the victim is forced to perform him- or herself. These actions are devoid of physical pain.

Physical dehumanization with physical pain concerns any behavior that not only diminishes the humanity of the victim but also inflicts a degree of physical pain upon that person. This group of behaviors was divided into two subgroups: abuse with instruments and without instruments. Instrument refers to any tool or weapon used by a 
Table 3 - Categories of Dehumanizing Behavior

1. Dehumanizing Living Conditions

2. Psychological Dehumanization

3. Physical Dehumanization without Physical Pain

4. Physical Dehumanization with Physical Pain - Abuse without Instruments

5. Physical Dehumanization with Physical Pain - Abuse with Instruments

perpetrator to inflict torture, pain, and humiliation. Such instruments range from guns, clubs, and machetes, through to fire, water, and attack dogs. Conversely, behaviors categorized as abuse without instruments refer to all actions in which pain and humiliation are inflicted without the explicit use of a tool. Beatings with hands and feet are examples of this type of physical dehumanization. Table 3 presents the dehumanizing behavior categories that we distinguished.

Once all the dehumanizing behaviors were divided among these five categories, a smaller list containing the cruelest behaviors was compiled. To ensure that our analysis was not only based on a compilation of cruel exceptions, the behaviors had to have been regularly inflicted. However, it must be acknowledged that since our analysis is based on the available second-hand literature, the precise frequency with which these behaviors occurred is unknown. Consequently, the behaviors chosen were those that were most common in the literature consulted. To compile this smaller list, behaviors were ranked according to the physical and psychological pain they inflicted on the victims. The categories included no pain, least pain, pain, most pain, and death. Death was further divided into "immediate death" and "prolonged death." Based on this categorization, the two most painful and most commonly employed behaviors for each genocide were chosen per dehumanizing behavior category. As a result, 10 behaviors representing the most common and most severe dehumanization were identified for each case. Consequently, a final list of 30 dehumanizing behaviors was compiled. To determine which genocide had the most severe dehumanization, this final list of 30 had to be ranked on a scale from one to 30 , with a score of 30 constituting the cruelest behavior and a score of one representing the least cruel behavior. We chose not to do the ranking ourselves to preclude any potential teleological result. Instead, we asked eight members of a working group who did not know the aim of our research to do the ranking for us. Although subjectivity was not completely defeated in this way, the opinions upon which the ranking was based were diversified and as a result, the extremes were averaged out and therefore play a smaller role.

\section{Social distance measured}

\section{Rwanda}

Rwanda's ethnic characteristics and tumultuous political history-during which first the Tutsi minority, supported by the colonizing Germans and Belgians, but since the 1960s the Hutu majority dominated-often leads to the misconception that the Hutu and the Tutsi were mutually exclusive tribes with little interaction.

In reality, however, they had much in common. They shared important customs, routines, and societal arrangements, spoke the same language, attended the same schools, shared the same religion (Christianity), frequented the same bars and shops, intermarried, and lived side by side. ${ }^{35}$ On a personal level, the Hutu and Tutsi shared 
Table 4 - Tutsi-Hutu Interaction in Percentages (weighted results)

\section{Before 1994, did you have any Tutsi \\ neighbors? $(\mathrm{N}=210)^{\mathrm{a}}$}

Before 1994, did you
have any Tutsi family
members? $(\mathrm{N}=205)^{\mathrm{b}}$

Before 1994, did you members? $(\mathrm{N}=205)^{\mathrm{b}}$

Before 1994, would
you have allowed
your child to marry
a Tutsi, or would
you have married a
Tutsi yourself?
$(\mathrm{N}=195)^{c}$

\begin{tabular}{lccc}
\hline Yes & 96.0 & 68.8 & 98.9 \\
No & 3.6 & 28.3 & 1.1 \\
I do not know & 0.4 & 2.9 & 0 \\
Total & 100 & 100 & 100 \\
\hline
\end{tabular}

a Only one respondent was not Hutu. Although he carried a Hutu identity card, he claimed his entire family was considered Tutsi.

b Any blood relation or relation by marriage is considered a family member.

c Married men and fathers were asked if their child would be permitted to marry a Tutsi, while unmarried men were asked if they themselves would marry a Tutsi woman.

amicable relations. They were neighbors, friends, and even members of the same family. ${ }^{36}$ This was also true of the génocidaires. Scott Straus conducted interviews with 210 convicted genocide perpetrators detained in 15 prisons across Rwanda where he asked the respondents four questions regarding interethnic proximity and intermarriage prior to the genocide. ${ }^{37}$ The answers are presented in Table 4. Almost all génocidaires claimed to have had Tutsi neighbors and would have allowed their child to marry a Tutsi, or would have married a Tutsi themselves. More than two thirds had Tutsi family members.

In addition, Straus enquired about the nature of Hutu-Tutsi interaction after 1990 but before 1994 when civil war broke out between the Rwandan Patriotic Front (RPF) - a Tutsi rebel group operating from Uganda-and the Hutu regime. These questions were designed to reveal the sentiments, either positive or negative, that characterized Hutu-Tutsi relations. Table $5^{38}$ shows that the greater majority claimed that relations were "positive" before 1994, while Table 6 shows that they remained "positive" even after the war began in 1990.

Table 5 - Relations between Hutu and Tutsi neighbors before 1994 in percentages (weighted results)

Before 1994, how were your relations

with your Tutsi neighbor? ( $\mathrm{N}=200)$

Positive ${ }^{a}$

86.5

'No problem'

11.2

Negative ${ }^{b}$

2.4

Total

100

a Responses that have been labelled as positive include: good, very good; truly good; more than $100 \%$; we were friends; we shared and we intermarried.

b Responses labelled as negative include: not good; we were friends before 1990; not good after 1990 and; they were accomplices. 
Table 6 - Relations between Hutu and Tutsi neighbors after 1990 in percentages (weighted results)

Did your relations with your Tutsi neighbor

change after the war began in 1990 ? $(\mathrm{N}=185)$

\begin{tabular}{lr} 
No & 86.5 \\
A little & 1.0 \\
Yes & 12.5 \\
Total & 100 \\
\hline
\end{tabular}

It must, of course, be acknowledged that the reliability of the results could be called into question due to the limited number of respondents on the one hand, and the fact that the respondents were exclusively perpetrators on the other. Straus's findings, however, mirror those from other sources. ${ }^{39}$

\section{Intermarriage}

Rwanda has a well-documented history of intermarriage. ${ }^{40}$ As generally described by the literature, mixed marriages were a common occurrence and can be traced back to pre- and early-colonial times. ${ }^{41}$ Callixte, a genocide survivor from the Ntarama locality, recalls that "about two thirds of Tutsi daughters would be married to a Hutu. But Hutu daughters married to Tutsi men were only 1 percent. Prospects were better for Tutsi daughters marrying Hutu men. They would get better opportunities." 42 Although this distribution is unlikely, we take Callixte's statement as further evidence that intermarriage was widespread. The high degree of intermarriage is also mentioned in other survivor testimonies and in witness and perpetrator accounts, albeit often in the context of inter-marital killing. ${ }^{43}$ According to one such a survivor, "Tutsi women married to Hutu were killed. I know only one who survived. The administration forced Hutu men to kill their Tutsi wives before they go to kill anyone else-to prove they were true interahamwe." ${ }^{4}$ This high rate of intermarriage is indicative of a society with little social distance between victim and perpetrator groups.

\section{Social Interaction}

Numerous personal accounts from both Hutu and Tutsi reveal close social relationships and personal friendships between the two groups. ${ }^{45}$ Hutu and Tutsi children and teenagers were relatively well integrated. Not only did they engage in shared leisure activities, but they were also part of the same sports teams. The Nyamata soccer team was one such group of players that encompassed both Hutu and Tutsi. ${ }^{46}$ Tite Rushita, interviewed by Hatzfeld, paints a picture of affable, cheerful relations in which the love of the game overrode any hint of ethnic tension. Although the civil war of the early 1990s marked the beginning of a swift decline in these once agreeable affiliations and the 1994 genocide pitted previous teammates against one another, their pre-1994 interactions were generally social and harmonious in nature. ${ }^{47}$ Rushita's description is reinforced by numerous testimonies from those who lived through the genocide. Angélique Mukamanzi conveys in her interview with Hatzfeld that her pre-1994 social circle was an ethnically mixed group of both Tutsi and Hutu. ${ }^{48}$ In Charles Mironko's interviews with a group of perpetrators residing in six Rwandan prisons, the majority alluded to a historical friendship between the two ethnic groups. ${ }^{49}$ While one respondent discusses regular 
social visits and blood brotherhood pacts, another talks of regular gift exchanges in the form of cows and other items..$^{50}$ The common premise connecting these testimonies is a high rate of amicable social interaction. Social distance can therefore be considered minimal within this category.

\section{Workforce Integration}

To some extent, the workforce that characterized post-colonial, pre-genocide Rwanda did show an ethnic division of labor. This was especially the case in the state sector. For instance, in the army and the intermediate to upper strata of government, transparent, anti-Tutsi policies were actively employed. Other areas of the public sector, although absent of official discriminatory measures, also exhibited a Hutu-dominant workforce. ${ }^{51}$ Consequently, this sector of Rwanda's pre-genocide workforce did not exhibit comprehensive ethnic integration.

However, the vast majority of Rwandans (both Hutu and Tutsi) did not participate in the public sector labor force, but rather found employment in peasant farming. ${ }^{52}$ Statistics taken from Rwanda's 1990 Human Development Report show that $92.8 \%$ of the Rwandan labor force at the time worked in agriculture..$^{53}$ The 1991 Rwandan census puts this number at only a slightly lower $90.9 \%$ ( $91.9 \%$ for Hutu, $85.5 \%$ for Tutsi). It further underlines the importance of agriculture by showing that only $5.5 \%$ of the population lived in cities.

Land and cattle have traditionally represented the two sides of Rwanda's agrarian and pastoral economy. Hutu tended to manage more of the food production in Rwandan society. Armed with farming implements such as the hoe and the machete, these farmers employed intensive labor to ensure the harvesting of crops. ${ }^{54}$ Generally uncomfortable in the company of livestock, Hutu planters considered cattle breeding to be an extravagance not befitting the typically arid landscapes of Rwanda. Animal husbandry was the historical pastime of the Tutsi pastoralists, who contributed to Rwanda's economy through cattle breeding and milk production. ${ }^{55}$ Consequently, while the vast majority of the Rwandan population was united in its agricultural occupations, differing specializations within the agrarian economy resulted in an agricultural workforce that was not comprehensively integrated. However, given that this agricultural specialization was not associated with differences in socioeconomic status-those who worked in agriculture were generally poor ${ }^{56}$-the social distance between the two groups can, from this perspective, still be considered small.

\section{Community Integration}

Pre-genocide Rwanda was initially divided into 11 prefectures. Table 7 depicts the ethnic distribution in these prefectures in 1991.

As the table shows, not a single one of these zones was restricted to just one ethnic group. In spite of the clear numerical dominance of the Hutu, the two groups lived side by side and generally without segregation. ${ }^{57}$ In fact, Straus's analysis of five communes from five prefectures shows that the Tutsi population was actually in excess of $10 \%$. Communes such as Giti, Musambira, and Kanzenze boasted quite large numbers of Tutsi. ${ }^{58}$ As a result, ethnic segregation along provincial, regional, or community lines does not appear to have been a feature of pre-genocide Rwanda.

Numerous survivor testimonies corroborate this portrait of community integration. Christine Nyiransabimana, a Tutsi, for instance, stated, "In my area, and in Nyamata town, I saw many Hutu relations and neighbors killing Tutsis every day of the 
Table 7 - Distribution (\%) of the Population of Rwanda by Prefecture and Ethnic Group in $1991^{\mathrm{a}}$

\begin{tabular}{llrlll}
\hline Prefecture & \multicolumn{3}{c}{ Ethnic Distribution } & & $\begin{array}{c}\text { Total Population } \\
\text { (numerical) }\end{array}$ \\
\cline { 2 - 5 } & Hutu & Tutsi & Twa & Other & \\
\hline Butare & 82.0 & 17.3 & 0.7 & 0.0 & 753,868 \\
Byumba & 98.2 & 1.5 & 0.2 & 0.0 & 775,935 \\
Cyangugu & 88.7 & 10.5 & 0.5 & 0.3 & 551,565 \\
Gikongoro & 86.3 & 12.8 & 0.8 & 0.1 & 465,814 \\
Gisenyi & 96.8 & 2.9 & 0.3 & 0.1 & 731,996 \\
Gitarama & 90.2 & 9.2 & 0.6 & 0.1 & 848,027 \\
Kibungo & 92.0 & 7.7 & 0.2 & 0.1 & 648,912 \\
Kibuye & 84.8 & 14.8 & 0.4 & 0.0 & 469,494 \\
Kigali & 90.8 & 8.8 & 0.4 & 0.1 & 905,632 \\
Kigali-ville & 81.4 & 17.9 & 0.3 & 0.4 & 221,806 \\
Ruhengeri & 99.2 & 0.5 & 0.2 & 0.1 & 766,795 \\
Total & 91.1 & 8.4 & 0.4 & 0.1 & $7,099,844$ \\
\hline
\end{tabular}

a Recensement général de la population et de I'habitat au 15 Août, 1991. Résultats définitifs, service national de Recensement, ministère du Plan, Kigali. [General census of population and housing on 15 August 1991. Final Results, National Census Service, Ministry of Planning, Kigali.]

genocide." ${ }^{59}$ In describing the death of her father, Angélique Mukamanzi stated, "He was run through by a Hutu neighbor." ${ }^{\circ 0}$ When talking about their neighbors and relations who took part in the killings, many survivors and witnesses referred to it as "turning Interahamwe." In other words, these individuals had displayed no previous alignment with Hutu extremism or radical militia groups. ${ }^{61}$ This expression not only implies a level of familiarity but also that those who were not expected to join the slaughter did. Essentially, the Hutu and Tutsi lived side by side in the same villages and in the same towns; there was little social distance with regard to their localities.

To conclude, in all categories of social distance studied, the Hutu and Tutsi displayed high levels of interaction. Social distance between these two groups prior to the 1994 genocide can therefore be considered to be small.

\section{Germany}

Assessing the social distance between the German perpetrators and the German-Jewish target group within Germany is not a straightforward task as the Nazis implemented widespread anti-Jewish legislation after their rise to power in 1933. As a result of these discriminatory laws, the social distance between the Jewish victim group and the German perpetrator group was deliberately manipulated in the years leading up to the extermination carried out by the Nazi regime.

In the years prior to Nazi rule and following the fall of Imperial Germany, the Weimar Republic was characterized by the widespread integration of Jews in all spheres of German life. The 1925 census calculated the Jewish population at 564,379 Israelites or $0.9 \%$ of the total German population. The demographic distribution of the population at that time showed that $66.8 \%$ of the Jewish populace lived in cities with over 100,000 inhabitants. Six of Germany's largest cities-Berlin, Frankfurt, Hamburg, Breslau, 
Leipzig, and Cologne-were home to $49 \%$ of all Jews in the country. $16 \%$ of the Jewish population resided in smaller cities with between 10,000 and 100,000 inhabitants, while the remaining $17 \%$ lived in towns and villages with less than 10,000 inhabitants. ${ }^{62}$ The assimilation of the Jewish community into the greater German society was especially evident in of the high rate of intermarriage before the genocide. Among all Jewish marriages between 1926 and 1930, 21.5\% constituted mixed marriages. ${ }^{63}$ This trend proceeded into the early days of Nazi rule, with $44 \%$ of German Jews choosing to marry non-Jews in $1933 .{ }^{64}$ In fact, roughly 35,000 Jews lived in mixed marriages in $1933 .{ }^{65}$ The Jews and gentiles enjoyed peaceful and indeed intimate relations during the pregenocide era. ${ }^{66}$

However, the final years of the Weimar Republic were decidedly tumultuous and witnessed an escalation of anti-Semitism, especially within the manifestos and propaganda tactics of political parties like the National Socialist German Workers' Party (NSDAP, "Nazi" Party). The 1933 Nazi takeover represented a turning point in German-Jewish integration. The years immediately preceding the genocide of European Jewry were characterized by widespread efforts on the part of the Nazi regime to set up barriers between German Jews and gentiles. The anti-Jewish policies and legislation outlined below not only depicts the ways in which the Nazis attempted to curtail their interactions, but also the extent to which these policies were actively pursued.

\section{Intermarriage}

The 1935 Law for the Protection of German Blood and Honor marked the first phase in the Nazi-led venture to curtail all interactions between Jews and gentiles. This law not only prevented German women under the age of 45 from working in Jewish households, hotels, and health resorts, but also prohibited mixed marriages and extramarital intercourse. ${ }^{67}$ Any mixed marriage occurring after the decree was not only automatically invalidated, but also considered to be an affirmation of guilt of extramarital intercourse. This decree was immediately supplemented with laws concerning the marriage practices of Mischlinge (crossbreeds) of the first and second degree-that is, with two or one Jewish grandparents, respectively. More specifically, marriages between a Mischling of the second degree and a Jew were prohibited, as were marriages between a Mischling of the second degree and another Mischling of the second degree. Furthermore, Mischlinge of the first degree could only marry other Mischlinge of the first degree or Jews. Through such policies, German-Jewish intermarriage was strictly curtailed.

\section{Social Interaction}

The 1930s were characterized by a number of laws that sought to reduce social interaction between Jews and gentiles. In April 1933, the Law against Overcrowding of German Schools was passed. It declared that the admission of non-Aryans into schools and colleges had to reflect the proportion of non-Aryans in the total German population. This law had far-reaching repercussions for Jewish students. By 1936, more than half of all Jewish students were forced to attend Jewish schools established by the Jewish community. By 1938, all Jewish students had been denied access to German schools and were as such enrolled in Jewish schools. ${ }^{68}$ Other restrictive measures included the introduction of travel regulations whereby Jews were forbidden access to dining and sleeping cars on all trains within Germany; the introduction of separate Jewish shopping hours by the Food and Agricultural Ministry; the introduction of separate Jewish hospitals; and denial of access to beaches. From September 1939 onwards, Jews were further 
constrained and isolated by the installation of an 8:00 p.m. curfew. Such limitations were exacerbated by the imposition of further restrictions on Jewish movements. For instance, the installation of private telephones in Jewish homes was outlawed. All communication and interaction with the gentile world was steadily reduced. ${ }^{69}$ The gap between the perpetrator group and the target group was steadily widened.

\section{Workforce Integration}

As 1933 unfolded and Hitler embarked on his first year of power, the position of Jews in Germany's economy was still strong and their role active. The majority of employed Jews found themselves in commerce. Such specialization stems from a historically low rate of Jewish employment in the civil service, the army, or agriculture. ${ }^{70}$ Therefore, while this sphere of German economic activity witnessed relatively little Jewish-German integration-only $1.2 \%$ of the total population in these professions were Jewish-other spheres such as commerce and enterprise exhibited higher Jewish representation. For example, in $1930,48 \%$ of all private bankers and $40 \%$ of all textile businesses were Jewish. The Jewish representation in liberal professions however, was nowhere near these high levels. In 1933, only $2 \%$ of all professional positions in Germany were held by Jews. $^{71}$

The position of Jews in all spheres of economic life was the first area targeted for segregation by the Nazi regime. In 1933, all non-Aryan officials were barred from positions in public office in the state railway company, the civil service, and the Reichsbank. $^{72}$ The ramifications of this law were not limited, however, to civil servants. Professionals such as Jewish doctors were suddenly deprived of their affiliation with state-sponsored health insurance programs, and Jewish notaries and lawyers were denied admission to the bar. ${ }^{73}$ Within a year of Nazi rule, Jewish representation in Germany's economic and public arenas had been severely curtailed. With the ensuing Aryanization and liquidation of Jewish enterprises and business establishments, the Jewish working sector was progressively and deliberately isolated from the greater German work force.

\section{Community Integration}

By 1939, forced emigration had reduced Germany's Jewish population to 330,892. According to the 1925 census, the Jewish community was considerably urbanized, a trend that increased rapidly after the Nazi takeover in 1933. In a bid to escape impoverishment, Jews abandoned the isolation of small towns and villages for the promise of Germany's big cities. The 1939 census shows that there were 82,788 Jews in Berlin and 14,461 in Frankfurt. ${ }^{74}$ Jewish migration within Germany was not, however, accompanied by integration into their new urban neighborhoods. The Nazi government greeted Jewish urbanization with renewed segregation efforts: namely residential separation. The Nazi administrative machine set about confining German Jews to separate housing blocs designated solely for Jewish inhabitants. Such a formidable task required widespread evictions and accompanying legislation. For instance, in 1938, a decree was passed in which German landlords were authorized to cancel the apartment leases of Jewish doctors. In 1939, this decree was compounded by another that allowed all German landlords to evict Jews if that landlord could provide a certificate declaring that the tenant could find alternative accommodation. ${ }^{75}$

Jewish emigration rose dramatically throughout this period. During the first 10 years of Hitler's reign, several hundreds of thousands left the country. By November 
1941, it was estimated that just 160,000 out of the 499,682 counted in the 1933 census remained in Germany. ${ }^{76}$ With such deteriorating numbers, Jewish-German interaction and integration in all areas, particularly living arrangements, would have been reduced.

\section{Establishing an Overall Social Distance Estimate}

From their inception into power through to the start of the genocide in 1941, the Nazi regime set about the systematic separation of the German Jews from the gentiles. The fact that these efforts were believed to be necessary indicates that social distance between gentiles and Jews was relatively small. Furthermore, successfully isolating German Jews from their non-Jewish counterparts was not guaranteed. Indeed, despite rigorous efforts, three events demonstrate the regime's failure in entrenching considerable social distance between Jews and gentiles.

The first such event was the 1933 boycott. Two months after Hitler's ascension to power, the Nazi party organized several mass meetings led by an established boycott committee. On the agenda was the implementation of a widespread national boycott on Jewish goods, shops, lawyers, businesses, and doctors. ${ }^{77}$ Predominantly driven by radical Sturmabteilung (SA) members, the events of the boycott included the placement of anti-Jewish placards and SA and Schutzstaffel (SS) guards outside such businesses. The guards were responsible for deterring shoppers by "informing" them of the Jewish ownership of such establishments. ${ }^{78}$ However, in spite of these efforts, the boycott was ultimately a failure. In truth, the German public largely ignored it and continued to go about their daily affairs, which included shopping at Jewish-owned stores. ${ }^{79}$ The significance of this evident failure is explicit in its illustration of the overall German sentiment and implicit in its illustration of the degree of community integration of the Jews. Combined with the two events below, this illustrates the failure of the Nazi regime to create the social distance it so desired.

The second event was the Kristallnacht. The night of 9 November 1938 was characterized by the destruction of 171 synagogues and 7,500 Jewish businesses, as well as the arrest and subsequent deportation of 20,000 Jews to concentration camps within the Reich, such as Dachau and Buchenwald. ${ }^{80}$ The brutality of this evening must not, however, mislead one into thinking that it represents anti-Jewish sentiment among the collective German population. The events of the Kristallnacht were no more than a cleverly orchestrated invention through which the destruction of Jewish synagogues and businesses were made to appear to be the work of the populace as a whole, when in fact it was solely the work of Nazi militias. ${ }^{81}$ The Nazis had to concoct a popular revolt because German civilians were simply not interested in an anti-Jewish pogrom. This provides evidence of a smaller social distance than that sought by the Nazis.

The third event is known as the 1943 Rosenstrasse incident or protest. Recall that German-Jewish intermarriage in 1933 and prior was relatively high. Essentially, it would have been those Germans in mixed marriages who had close personal contact with Jews who were most resistant to anti-Jewish policies and propaganda. ${ }^{82}$ It was within this context that the 1943 Rosenstrasse incident occurred. At the start of that year, it was estimated that there were still 16,760 mixed marriages within Germany proper. It was primarily the Jewish husbands of these marriages who were incarcerated by the Gestapo in early 1943 and held in a former welfare office of the Jewish community at Rosenstrasse 2-4 (Rose Street) in Berlin. In response to these arrests, non-Jewish spouses and relatives openly resisted Nazi rule and gathered themselves in significant numbers outside the building. ${ }^{83}$ The SS, however, did not arrest or shoot the women 
standing in defiance. Instead, the Nazis negotiated with the protesters and finally released the detainees. ${ }^{84}$ The fact that the imprisoned men were released indicates a small social distance between some Germans and Jews. The Nazis were aware that the popularity of the persecution of the Jews was limited and were anxious not to lose support for their regime. In an effort to prevent social unrest, the regime ignored its ideological principles and let the Jewish men go free. ${ }^{85}$

The final conclusion to be drawn from this section on social distance is less straightforward than the one drawn in the case of Rwanda. The years preceding the 1933 Nazi takeover consisted of peaceful relations and increasing integration. ${ }^{86}$ However, the ascension of the Nazi party to power brought with it a number of anti-Jewish policies and laws. ${ }^{87}$ Through the administrative apparatus of Hitler's machine, antiJewish decrees sought to isolate the Jews and corrode German-Jewish interaction. However, in spite of such extensive legislation, there were several incidents which point to the maintenance of small social distances. Consequently, although legislation made strides toward widening the social distance between the two groups, interaction continued to occur. The bonds that connected the two were therefore still present, though admittedly weakened.

\section{Eastern Europe}

Following the model of the previous sections, this paragraph addresses the degree of social distance between the Polish and Baltic victim groups and the German perpetrator group prior to the outbreak of the Jewish genocide in Eastern Europe (Poland and the Baltic States). At this point, however, we depart from the previous composition. Specifically, the perpetrator group in this case refers to the German army that invaded Poland in 1939 and the Einsatzgruppen-small, mobile killing units of the Sicherheitspolizei (Sipo) and Sicherheitsdienst (SD) - that invaded the USSR in $1941 .^{88}$ The geographic distance separating the victim and perpetrator groups limits the likelihood of social contact, therefore rendering the social distance categories obsolete. Simple logistics imply that intermarriage, social interaction, workforce integration, and community integration on anything other than a minimal level were absent. It can therefore be assumed that the overall rate of victim and perpetrator group interaction prior to the outbreak of genocide was so minimal that the social distance between them can be classified as large.

\section{Summing Up}

The social distance in each pre-genocide context is summarized in Table 8.

Rwanda constituted the case with the smallest social distance. The Hutu perpetrator group and the Tutsi victim group were not only characterized by high rates of intermarriage and social integration, but were also part of the same general workforce, social circles, and neighborhoods. As a result, they had the greatest rate of interaction prior to the outbreak of genocide in 1994. In the context of Eastern Europe, social distance between the German perpetrator group and the Polish and Baltic victim groups was, for all intents and purposes, nonexistent. Due to the geographic distance separating the two, any meaningful interaction was unlikely. Ergo, it can be stated that the social distance between the perpetrator group and the victim group prior to the outbreak of the Jewish genocide in Eastern Europe was large.

Comparatively speaking, the social distance prevalent in Western Europe (i.e., Germany) falls somewhere between that of the other two genocides. This conclusion rests 
Table 8 - Social Distance Prior to the Genocides in Rwanda, Western Europe and Eastern Europe

Theatre

Socio-Demographic Condition

\begin{tabular}{llllll}
\cline { 2 - 5 } & $\begin{array}{l}\text { Rate of } \\
\text { Inter- } \\
\text { marriage }\end{array}$ & $\begin{array}{l}\text { Rate of } \\
\text { Social } \\
\text { Interaction }\end{array}$ & $\begin{array}{l}\text { Rate of } \\
\text { Workforce } \\
\text { Integration }\end{array}$ & $\begin{array}{l}\text { Rate of } \\
\text { Community } \\
\text { Integration }\end{array}$ & $\begin{array}{l}\text { Total } \\
\text { Social } \\
\text { Distance }\end{array}$ \\
\hline $\begin{array}{l}\text { Rwanda } \\
\text { Germany } \\
\text { (Western }\end{array}$ & $\begin{array}{l}\text { High } \\
\text { Intermediate }\end{array}$ & $\begin{array}{l}\text { High } \\
\text { Intermediate }\end{array}$ & $\begin{array}{l}\text { High } \\
\text { Intermediate }\end{array}$ & $\begin{array}{l}\text { High } \\
\text { Intermediate }\end{array}$ & $\begin{array}{l}\text { Small } \\
\text { Average }\end{array}$ \\
$\begin{array}{l}\text { Europe) } \\
\begin{array}{l}\text { Poland and } \\
\text { Baltic States } \\
\text { (Eastern }\end{array}\end{array}$ & Low & Low & Low & Low & Large \\
Europe) & & & & & \\
\hline
\end{tabular}

on the bisection of German-Jewish interactions before the outbreak of genocide. The interaction between these two groups resembled two competing forces: high rates of German-Jewish interaction before 1933 on the one hand, and institutionalized attempts by the Nazi government to separate them on the other. Although not entirely successful, the Nazis did manage to widen the social distance between these two groups. Consequently, this case lies somewhere between Rwanda and Eastern Europe.

\section{Dehumanization Measured}

Table 9 below contains the 30 selected dehumanizing behaviors that the perpetrator groups inflicted on victim groups. The table also illustrates which behavior belonged to which genocide, as well as the method of categorization. It is important to keep in mind that the table given to the participants only contained the behaviors. Following the procedure outlined under "Measuring Severity of Dehumanization," these behaviors were ranked based on their severity/cruelty.

The respondents' answers enabled us to formulate several rankings of dehumanizing behaviors. ${ }^{89}$ They will be presented below.

Table 10 gives an overview of the different types of dehumanizing behavior per case study and the average dehumanization score that our respondents attributed to them.

In terms of total severity of dehumanization, Rwanda received the highest total average score of 19.6. Eastern Europe was placed second with a total score of 15.0, while Western Europe received the lowest score at 11.9. When we look at the subtotals of the dehumanizing behavior categories, Rwanda's position as the genocide manifesting the most severe behavior is further cemented. As Table 10 shows, Rwanda received the highest score in three of the five categories. The Holocaust in Western Europe, on the other hand, clearly exhibits the least severe dehumanizing behavior, despite having received the highest score for psychological dehumanization (10.2). The Holocaust in Eastern Europe is placed between Rwanda and Western Europe with several middleranking scores.

Finally, we looked at the specific types of behavior with the five highest scores. The figure below displays the results in the form of a column chart. The values represent the data presented in Table 9. 
Table 9 - The Dehumanization Behavior List

\begin{tabular}{|c|c|c|c|}
\hline & Dehumanizing Behavior & $\begin{array}{l}\text { Genocide } \\
\text { Case }\end{array}$ & $\begin{array}{l}\text { Category of Dehumanization } \\
\text { Behavior }\end{array}$ \\
\hline 1 & $\begin{array}{l}\text { Members of the victim group were } \\
\text { forced into slave labor for } 12 \text { hours a } \\
\text { day. }\end{array}$ & $\begin{array}{l}\text { Western } \\
\text { Europe }\end{array}$ & Dehumanizing living conditions \\
\hline 2 & $\begin{array}{l}\text { Members of the victim group were } \\
\text { forced to march huge distances with } \\
\text { no food or rest. }\end{array}$ & $\begin{array}{l}\text { Western } \\
\text { Europe }\end{array}$ & Dehumanizing living conditions \\
\hline 3 & $\begin{array}{l}\text { Members of the victim group were } \\
\text { forced to attend daily roll call. }\end{array}$ & $\begin{array}{l}\text { Western } \\
\text { Europe }\end{array}$ & Psychological dehumanization \\
\hline 4 & $\begin{array}{l}\text { Skin of dead victims would be tanned } \\
\text { and stored for later use. }\end{array}$ & $\begin{array}{l}\text { Western } \\
\text { Europe }\end{array}$ & Psychological dehumanization \\
\hline 5 & $\begin{array}{l}\text { Members of the victim group were } \\
\text { made to stand naked waiting to be } \\
\text { shot. }\end{array}$ & $\begin{array}{l}\text { Western } \\
\text { Europe }\end{array}$ & $\begin{array}{l}\text { Physical dehumanization } \\
\text { without physical pain }\end{array}$ \\
\hline 6 & $\begin{array}{l}\text { Members of the victim group were } \\
\text { herded like sheep by members of the } \\
\text { perpetrator group. }\end{array}$ & $\begin{array}{l}\text { Western } \\
\text { Europe }\end{array}$ & $\begin{array}{l}\text { Physical dehumanization } \\
\text { without physical pain }\end{array}$ \\
\hline 7 & $\begin{array}{l}\text { Men from the victim group were } \\
\text { kicked and dealt heavy blows. }\end{array}$ & $\begin{array}{l}\text { Western } \\
\text { Europe }\end{array}$ & $\begin{array}{l}\text { Physical dehumanization with } \\
\text { physical pain (abuse without } \\
\text { instruments) }\end{array}$ \\
\hline 8 & $\begin{array}{l}\text { Members of the victim group were } \\
\text { forced to stand for a night outside in } \\
\text { the rain. }\end{array}$ & $\begin{array}{l}\text { Western } \\
\text { Europe }\end{array}$ & $\begin{array}{l}\text { Physical dehumanization with } \\
\text { physical pain (abuse without } \\
\text { instruments) }\end{array}$ \\
\hline 9 & $\begin{array}{l}\text { The following medical experiments } \\
\text { were inflicted on members of the } \\
\text { victim group: } \\
\text { Hypothermia where victims were } \\
\text { placed in freezing water } \\
\text { Infectious diseases were injected } \\
\text { into victims } \\
\text { High altitude experiments using } \\
\text { low-pressure chambers } \\
\text { Pharmacological where victims } \\
\text { were subjected to poisons or gas to } \\
\text { test possible antidotes } \\
\text { Sterilization } \\
\text { Surgery such as bone-grafting } \\
\text { experiment } \\
\text { Traumatic Injuries to simulate battle } \\
\text { wounds }\end{array}$ & $\begin{array}{l}\text { Western } \\
\text { Europe }\end{array}$ & $\begin{array}{l}\text { Physical dehumanization with } \\
\text { physical pain (abuse with } \\
\text { instruments) }\end{array}$ \\
\hline 10 & $\begin{array}{l}\text { Members of the victim group } \\
\text { experienced beatings with rifle butts, } \\
\text { clubs, and whips. }\end{array}$ & $\begin{array}{l}\text { Western } \\
\text { Europe }\end{array}$ & $\begin{array}{l}\text { Physical dehumanization with } \\
\text { physical pain (abuse with } \\
\text { instruments) }\end{array}$ \\
\hline 11 & $\begin{array}{l}\text { Up to } 200 \text { members of the victim } \\
\text { group were forced into closed cattle } \\
\text { wagons with no fresh air. }\end{array}$ & $\begin{array}{l}\text { Eastern } \\
\text { Europe }\end{array}$ & Dehumanizing living conditions \\
\hline
\end{tabular}


Table 9 - (continued)

\begin{tabular}{|c|c|c|c|}
\hline & Dehumanizing Behavior & $\begin{array}{l}\text { Genocide } \\
\text { Case }\end{array}$ & $\begin{array}{l}\text { Category of Dehumanization } \\
\text { Behavior }\end{array}$ \\
\hline 12 & $\begin{array}{l}\text { Members of the victim group were } \\
\text { forced to live in fenced-off ghettos in } \\
\text { unsanitary conditions that resulted in } \\
\text { the repeated outbreak of epidemics } \\
\text { and high mortality rates. }\end{array}$ & $\begin{array}{l}\text { Eastern } \\
\text { Europe }\end{array}$ & Dehumanizing living conditions \\
\hline 13 & $\begin{array}{l}\text { Members of the victim group were } \\
\text { assigned numbers to replace their } \\
\text { names. }\end{array}$ & $\begin{array}{l}\text { Eastern } \\
\text { Europe }\end{array}$ & Psychological dehumanization \\
\hline 14 & $\begin{array}{l}\text { Laughing and jeering accompanied } \\
\text { beatings by the perpetrators. }\end{array}$ & $\begin{array}{l}\text { Eastern } \\
\text { Europe }\end{array}$ & Psychological dehumanization \\
\hline 15 & $\begin{array}{l}\text { Members of the victim group were } \\
\text { made to march naked to pits and } \\
\text { forced to lie on top of corpses. }\end{array}$ & $\begin{array}{l}\text { Eastern } \\
\text { Europe }\end{array}$ & $\begin{array}{l}\text { Physical dehumanization } \\
\text { without physical pain }\end{array}$ \\
\hline 16 & $\begin{array}{l}\text { Women from the victim group were } \\
\text { forced to throw their children into } \\
\text { graves alive where they would be shot }\end{array}$ & $\begin{array}{l}\text { Eastern } \\
\text { Europe }\end{array}$ & $\begin{array}{l}\text { Physical dehumanization } \\
\text { without physical pain }\end{array}$ \\
\hline 17 & $\begin{array}{l}\text { Members of the victim group were } \\
\text { forced to stand for hours in the } \\
\text { freezing cold, rain and snow and often } \\
\text { froze to death. }\end{array}$ & $\begin{array}{l}\text { Eastern } \\
\text { Europe }\end{array}$ & $\begin{array}{l}\text { Physical dehumanization with } \\
\text { physical pain (abuse without } \\
\text { instruments) }\end{array}$ \\
\hline 18 & $\begin{array}{l}\text { Female members of the victim group } \\
\text { were raped. }\end{array}$ & $\begin{array}{l}\text { Eastern } \\
\text { Europe }\end{array}$ & $\begin{array}{l}\text { Physical dehumanization with } \\
\text { physical pain (abuse without } \\
\text { instruments) }\end{array}$ \\
\hline 19 & $\begin{array}{l}\text { Members of the victim group were } \\
\text { beaten to death with clubs and iron } \\
\text { rods. }\end{array}$ & $\begin{array}{l}\text { Eastern } \\
\text { Europe }\end{array}$ & $\begin{array}{l}\text { Physical dehumanization with } \\
\text { physical pain (abuse with } \\
\text { instruments) }\end{array}$ \\
\hline 20 & $\begin{array}{l}\text { Attack dogs would be set on members } \\
\text { of the victim group. }\end{array}$ & $\begin{array}{l}\text { Eastern } \\
\text { Europe }\end{array}$ & $\begin{array}{l}\text { Physical dehumanization with } \\
\text { physical pain (abuse with } \\
\text { instruments) }\end{array}$ \\
\hline 21 & $\begin{array}{l}\text { Members of the victim group were } \\
\text { deprived of methods to collect water, } \\
\text { which led to dehydration and death. }\end{array}$ & Rwanda & Dehumanizing living conditions \\
\hline 22 & $\begin{array}{l}\text { Members of the victim group were } \\
\text { forced to live in mud and swamps in } \\
\text { the company of snakes, mosquitoes } \\
\text { and corpses. }\end{array}$ & Rwanda & Dehumanizing living conditions \\
\hline 23 & $\begin{array}{l}\text { Members of the victim group were } \\
\text { called worms, cockroaches and } \\
\text { snakes. }\end{array}$ & Rwanda & Psychological dehumanization \\
\hline 24 & $\begin{array}{l}\text { The killers would laugh, sing and } \\
\text { dance while they went about the task } \\
\text { of killing. }\end{array}$ & Rwanda & Psychological dehumanization \\
\hline 25 & $\begin{array}{l}\text { Women from the victim group were } \\
\text { forced to march naked while being } \\
\text { forced to sing songs. }\end{array}$ & Rwanda & $\begin{array}{l}\text { Physical dehumanization } \\
\text { without physical pain }\end{array}$ \\
\hline
\end{tabular}

(Table continued on next page) 
Table 9 - (continued)

\begin{tabular}{|c|c|c|c|}
\hline & Dehumanizing Behavior & $\begin{array}{l}\text { Genocide } \\
\text { Case }\end{array}$ & $\begin{array}{l}\text { Category of Dehumanization } \\
\text { Behavior }\end{array}$ \\
\hline 26 & $\begin{array}{l}\text { Members of the victim group were } \\
\text { forced to kill their own children and } \\
\text { spouses were forced to kill their } \\
\text { partners. }\end{array}$ & Rwanda & $\begin{array}{l}\text { Physical dehumanization } \\
\text { without physical pain }\end{array}$ \\
\hline 27 & $\begin{array}{l}\text { Female members of the victim group } \\
\text { experienced systematic gang rape } \\
\text { from up to } 15 \text { perpetrators. }\end{array}$ & Rwanda & $\begin{array}{l}\text { Physical dehumanization with } \\
\text { physical pain (abuse without } \\
\text { instruments) }\end{array}$ \\
\hline 28 & $\begin{array}{l}\text { Children from the victim group were } \\
\text { slammed against the walls until dead. }\end{array}$ & Rwanda & $\begin{array}{l}\text { Physical dehumanization with } \\
\text { physical pain (abuse without } \\
\text { instruments) }\end{array}$ \\
\hline 29 & $\begin{array}{l}\text { Members of the victim group would } \\
\text { have their body parts cut off and be } \\
\text { left to die slowly. }\end{array}$ & Rwanda & $\begin{array}{l}\text { Physical dehumanization with } \\
\text { physical pain (abuse with } \\
\text { instruments) }\end{array}$ \\
\hline 30 & $\begin{array}{l}\text { Female members of the victim group } \\
\text { would have their vaginas punctured } \\
\text { with spears, arrows, or pointed sticks } \\
\text { and then have their genitals cut off } \\
\text { entirely. }\end{array}$ & Rwanda & $\begin{array}{l}\text { Physical dehumanization with } \\
\text { physical pain (abuse with } \\
\text { instruments) }\end{array}$ \\
\hline
\end{tabular}

Table 10 - Average Severity of dehumanization Score per Dehumanization Category (with the scores for the categories: abuse with instruments and abuse without instruments)

\begin{tabular}{lccc}
\hline Dehumanizing Behavior Category: & Rwanda & $\begin{array}{c}\text { Eastern } \\
\text { Europe }\end{array}$ & $\begin{array}{c}\text { Western } \\
\text { Europe }\end{array}$ \\
\hline 1 Dehumanizing Living Conditions & 15.05 & 11.9 & 9.75 \\
2 Psychological Dehumanization & 9.3 & 6.65 & 10.2 \\
3 Physical Dehumanization without Physical Pain & 21.2 & 21.5 & 10.1 \\
$4 \quad \begin{array}{l}\text { Physical Dehumanization with Physical Pain- } \\
\text { Abuse without Instruments }\end{array}$ & 25.3 & 18.05 & 10.10 \\
$5 \quad \begin{array}{l}\text { Physical Dehumanization with Physical Pain- } \\
\quad \text { Abuse with Instruments }\end{array}$ & 27.15 & 16.85 & 19.45 \\
\begin{tabular}{l} 
Total Average Score \\
\hline
\end{tabular} & 19.6 & 15.0 & 11.9 \\
\hline
\end{tabular}

As one can see from this figure, four out of five of the highest-scoring behaviors originated in Rwanda, thereby solidifying Rwanda's position as the genocide with the most severe dehumanization.

\section{Severity of Dehumanization Scores and Social Distance Findings Combining Results}

When one combines the above findings for severity of dehumanization with those for social distance, the relationship between the two variables becomes visible. While Rwanda exhibited the least social distance but the greatest severity of dehumanization, Eastern Europe, with its much greater social distance, displayed less severe dehumanization.

These findings imply that a high degree of social proximity dictates a high degree of severity of dehumanization during the killing operations of genocide. Conversely, the 


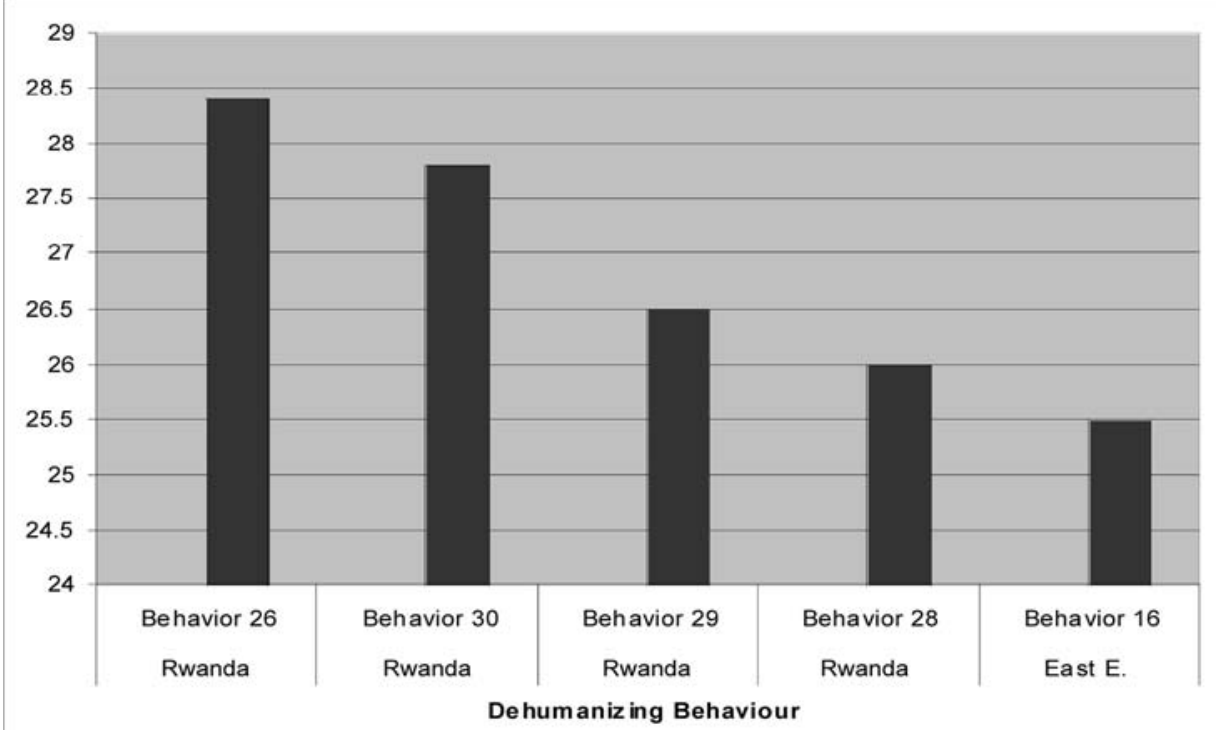

Figure 1 Behaviors with the Five Highest Scores

less social interaction there is prior to the outbreak of genocide, the less severe the dehumanization behaviors appear to be during the genocide.

These results corroborate our hypothesis, which had postulated that dehumanization reduces the moral and cognitive obstacles that stand in the way of killing fellow human beings. As explained by Bandura, empathetic emotions are elicited when one perceives another as human. ${ }^{90}$ The elicitation of these feelings stems from perceived similarity and identification. Yet, if perceived similarity is replaced with perceived difference, the victim is removed from the moral, human realm and thus becomes destructible. ${ }^{91}$ In this way, dehumanization can break the bonds that tie human beings to one another. Consequently, no matter the surrounding contexts, circumstances, cultures, or environments, killing human beings is easier when those targeted are no longer bound to the killers by their shared humanity. In support of this reasoning, one Nazi commandant maintained that the degradation inflicted on concentration camp prisoners destined to die was administered not with the aim of inflicting cruelty for cruelty's sake, but rather to severely diminish the humanity of the prisoner. In this way, those operating the gas chambers could carry out their duties with minimal distress. ${ }^{92}$ When questioned about a mass of bodies, another Nazi camp guard said, "It had nothing to do with humanity, it couldn't have; it was a mass - a mass of rotting flesh."93

In light of the results of this research, it can be stated that if dehumanization is necessary in the mass murder of strangers (the Eastern Europe case), it appears absolutely imperative in the mass murder of acquaintances (the Rwanda case). Breaking the ties that bind human beings is difficult in itself, so breaking ties that have been solidified by social closeness is even harder and requires more effort. As noted by Albert Bandura, "the joys and suffering of similar persons are more vicariously arousing than are those of strangers". ${ }^{94}$ Therefore, the termination of empathetic feelings and subsequent 
destruction of shared human bonds will require greater dehumanization if the targeted individual is known to the perpetrator than if they were unknown. It is therefore unsurprising that out of all three cases the perpetrators in Rwanda infused their killing operations with the most severe dehumanization. As stated by Rwililiza, a survivor of that genocide, "They cut and mutilated Tutsis to take from them all that was human and thus kill them more easily." 95 The same survivor goes on to articulate, "Neighbors of longstanding turned in a matter of hours into beasts." ${ }^{196}$ Both statements imply a strong relationship between severity of dehumanization on the one hand and the close social proximity of the victim and perpetrator groups on the other.

In contrast to the Rwanda case, the genocide in Eastern Europe was defined by a vast social distance separating the German perpetrator group and the Eastern European (Polish and Baltic) victim groups. They were not only physically separated but they were also culturally and linguistically distinct. The victim group therefore represented an entirely foreign body requiring a level of severity of dehumanization necessary only to break the common bonds of general humanity, not those solidified by social closeness. With the paper's theoretical framework constantly in mind, it can be concluded that this entrenched social distance enabled the perpetrator group to approach their victims with a level of detachment not possible in Rwanda and as such, less severe dehumanization was administered. As stated by Felix Landau, an Einsatzgruppen member, on recounting the experience of shooting Jews in the Eastern territories, "Strange, I am completely unmoved. No pity, nothing. That's the way it is and then it's all over. My heart beats just a little faster when involuntarily I recall the feelings and thoughts I had when I was in a similar situation." 97

Importantly, brief attention should be given to the role played by local perpetrators within the Baltic region and their dehumanization practices, as it strengthens our case further. Recall, among the German forces that invaded the USSR were four units of the Sicherheitspolizei and Sicherheitsdienst referred to as Einsatzgruppen. A main purpose of these unites was to kill all Jewish inhabitants as they came into contact with them. ${ }^{98}$ The swiftness with which these units operated was reflected in the magnitude of the killings they carried out. For example, Einsatzgruppe A, which was sent to the major cities of the Baltic States with their 250,000 Jewish inhabitants, ${ }^{99}$ reported the murders of 125,000 Jews by October 151941 - just four months after their initial invasion. ${ }^{100} \mathrm{In}$ fact, the overall proportion of Baltic Jewish deaths constitutes one of the largest in Europe at $95 \%{ }^{101}$ The type of execution murder practice which predominated at the hands of the Einsatzgruppen was mass outdoor shootings. ${ }^{102}$ As described by Kaufmann "women and men embraced in farewell in the face of death. The luckless ones stood there in their thousands and had to wait their turn, watching their brothers and sisters being shot." 103 He goes on to describe, "it was the Germans who dragged Jews into the prayer house, not to pray but to be burned alive. Thus the prayer house disappeared, as did the old kworesman (gravedigger) R. Chaim." 104 The sheer number of these deaths can be attributed to a straightforward approach backed by vast army assistance. However, one cannot overlook the role played by local collusion. ${ }^{105}$

The Einsatzgruppen in the former USSR territories were aided in their killing operations by local auxiliary police units. ${ }^{106}$ In fact, vast numbers of Baltic Jews were murdered by their fellow Lithuanians, Latvians and Estonians, and dehumanization was particularly severe. As one Lithuanian survivor recalls, "the coarse Lithuanian mob [...] acted with such beastly cruelty that by comparison, the Russian pogroms seemed like 
humanitarian deeds." 107 Another survivor recalls: "The Lithuanian murderers [. . . ] brought 550 men to the cemetery, forced them to dig a large pit and then ordered them to kill each other with the shovels they were holding. A father was made to kill his son, a brother his own brother." 108 The Lithuanians involved in the killings were often former customers, neighbors and classmates, ${ }^{109}$ which provides further corroboration for our hypothesis. So while local Baltic perpetrators are not included in the German perpetrator group under examination and their genocidal behavior has no bearing on the results, the level of their dehumanization is interesting and worth mentioning given the hypothesis posed.

Finally, the correlation between small social distance and severe dehumanization finds additional support in previous studies, particularly the 1971 Stanford Prison Experiment conducted by Phillip Zimbardo. To briefly explain, a sample of 24 college students from Stanford were selected to take part in a two-week experiment regarding the psychology of prison life. These participants were randomly divided into two groups - prisoners and guards - and were left to assume their respective roles. After just six days, the experiment was terminated due to the extreme levels of dehumanization and humiliation inflicted by the "guards" onto the "prisoners." 110 Although not a genocidal incident, this experiment illustrates characteristics that are present in genocide. Essentially, it pits two defined groups against one another where one group holds a dominant, more powerful position and the other is weaker and becomes victimized. Furthermore, the groups in this example are separated by relatively small social distance. The volunteers were characterized by several common features, which in turn assumes diminutive social distance. Specifically, they were all male college students of the same age, from middle class backgrounds and lived in the same area. ${ }^{111}$ It can therefore be assumed that the close social proximity defining these two groups played a role in the subsequent severity of dehumanization exhibited by those who played the part of the guards. In keeping with the reasoning of this paper's proposed hypothesis, severe dehumanization was required in order to shatter the ties of humanity and social closeness thereby enabling the guards to perform their duties with greater ease.

The social distance-severity of dehumanization correlation intimated by Zimbardo's study is strengthened further when compared to the BBC Prison Study. As with the Stanford Prison Experiment, this 2002 study, broadcasted on BBC, pitted a prisoner group against a guard group in a simulated prison scenario in order to study the psychological and social ramifications. Unlike, Zimbardo's study, however, the participants were separated by a much larger social distance. The fifteen participants were composed of mentally stable men from all over Britain. ${ }^{112}$ Another distinction between the two studies lies in the contrasting behavior of the guards. In the BBC experiment the guards did not automatically adjust to their roles nor did they become accustomed to the power that came with those roles. More importantly, they did not humiliate nor did they dehumanize the prisoners under their charge. ${ }^{113}$ These particular developments confirm the proposed relationship between social proximity and severity of dehumanization. It is likely that the social distance was much smaller between the participants in the Stanford experiment, hence the severity of dehumanization. Conversely, the social proximity between the BBC participants was much greater limiting the necessary severity of dehumanization. Thus, the Zimbardo experiment conducted in 1971 along with the BBC Prison Study conducted in 2002 effectively corroborates our hypothesis. 


\section{The Anomaly of Germany (Western Europe)}

When applying the same comparative lens to the findings for Germany, the inverse relationship between social distance and severity of dehumanization was not found. Recall, the results for Germany revealed a social distance of a medium degree. Bisected by two opposing forces, Germany was left with a social distance that was not as extensive as desired by the Nazi regime, yet neither was it of the social proximity evident in Rwanda. Moreover, the perpetrators within this context exhibited the least severe dehumanization behavior out of all three cases. If the findings were to support the reasoning behind the hypothesis, this case would have exhibited greater severity of dehumanization than Eastern European where the social distance was larger. The reasons behind these particular results shall be tentatively explained below.

The relatively mild dehumanization evident in the case of Germany finds its roots in the basic character of the Nazi regime and an underlying concern of Nazi bureaucrats for the psychological and spiritual wellbeing of their killers. The Nazi perpetrators were discouraged from excessive use of cruelty, torture and brutality, not just because such savagery was considered counterproductive to the organized nature of the genocide machine, ${ }^{114}$ but also because of their psychological wellbeing. The psyches of those employed to kill were considered to be of great importance to the functioning of the entire operation. ${ }^{115}$ As a result, a number of steps were taken to restrict opportunities for savage depravity and to lessen trauma and damage to the psyches of the perpetrators. It was these steps that set the stage for more mild forms of dehumanization behavior.

First and foremost, the workings of the Holocaust were kept sharply in check by the prohibition of unofficial killings. ${ }^{116}$ In the clinical style so favoured by the Nazis, killings fuelled by bloodlust or the emotional desires of the perpetrator were considered beneath the superiority espoused by the Nazi regime. As a result, any action or killing believed to be driven by cruel, sexual or egocentric intentions were punishable offences. Killings that were conducted in line with Nazi legislation or under the umbrella of political idealism went without penalty. ${ }^{117}$ Consequently, through these administrative and legal restrictions, the perpetrators were limited in their opportunities to kill German Jews brutally and were therefore restricted in their ability to dehumanize severely.

Second, and perhaps most importantly, the Nazi machine attempted to ease any damage to the psyches and souls of the perpetrators by distancing them from their victims as much as possible. ${ }^{18}$ To clarify, despite the large social distance characterizing the perpetrator and victim groups in Eastern Europe and the severe dehumanization inflicted by the perpetrators, the mass shootings still proved traumatic for many perpetrators. Not all the killers were able to approach the mass shootings with the degree of detachment illustrated by Felix Landau above. In truth, these mass shootings involved pervasive psychological distress that was illustrated by the widespread incidences of alcoholism. ${ }^{119}$ Rudolph Höss, SS Kommandant in Auschwitz, illustrates the extent of alcohol used by the firing squad men: "Most of the members of the Special Action Squads drank a great deal to help get through this horrible work. According to Captain Rudolf Hoffle's accounts, the men of Globocnik's extermination section drank tremendous quantities of alcohol."120 Such extensive alcoholism was not limited to those perpetrators stationed in the former USSR territories. As illustrated by Browning, alcoholism was equally prevalent amongst the firing squads of the Order Police stationed in Poland. ${ }^{121}$ Another reaction to the killings was the occurrence of suicide. As recalled by Höss: "Another thing on my mind was the many suicides among the ranks 
of the SS Special Action Squads who could no longer mentally endure wading in the blood bath. Some of them went mad." 122

In light of this, the Nazi administrators were impelled to find a solution for the more extreme "soul damage" and psychological distress that would certainly accompany the killing of Western and specifically German Jews who were of a closer social proximity to the perpetrator group. ${ }^{123}$ The solution was the gas chamber. Höss explains the reasoning behind it in the mass annihilation of Jews from Germany and other parts of the West: "Only gas was suitable since killing by shooting the huge numbers expected [. . .] would also be a tremendous strain on the SS soldiers who would have to carry out the order as far as the women and children were concerned." 124 Höss explains further: "Now we had discovered the gas and the procedure [. . .] I had had enough of hostage executions, and the mass killings by firing squad ordered by Himmler and Heydrich. Now I was at ease. We were all saved from these blood baths." 125

Consequently, an artificial distance was imposed between perpetrator and victim that not only restricted the potential for greater psychological trauma, but also the severity of dehumanization that would have occurred with the killing of socially closer German and other Western European Jews. This artificial distance was increased further by the employment of Jewish inmates both in the gassing process and also in the subsequent clearing away of the dead bodies. ${ }^{126}$ The burial of the corpses as well as their later incineration was also the responsibility of the Jews. ${ }^{127}$

The pervasive concern for the psychological wellbeing of the perpetrators allowed the mass slaughter of the Jews from Germany, and by extension from Western Europe, to ensue with milder dehumanization behavior. The synthetic distance imposed during the killing operations of the German Jews therefore provides an explanation as to why the German (Western Europe) case received the lowest score on the scale of severity of dehumanization.

\section{Conclusion and Discussion}

This paper developed the hypothesis that the smaller the social distance between the perpetrator group and the victim group prior to genocide the more severe the dehumanization behaviors of the perpetrators during genocide. In order to illustrate this hypothesis, the paper employed a literature-based analysis supplemented by a Vignetteorientated severity scale in three genocide cases: Rwanda, the Holocaust as it occurred in Western Europe and the Holocaust as it occurred in Eastern Europe.

The results show that Rwanda - the case with the smallest victim-perpetrator social distance - displayed the most severe dehumanization behavior. Conversely, Eastern Europe (Poland and the Baltic States) - the case with the greatest social distance between the German perpetrator group and the Jewish Polish and Baltic victim group manifested less severe dehumanization behavior. From these two case findings, it appears as if the smaller the social distance preceding the outbreak of genocide the greater the severity of dehumanization during the killing operations of genocide. The corroboration of this hypothesis is, however, encumbered by the Western Europe (Germany) anomaly.

Despite greater intimacy between its victim and perpetrator groups, Western Europe displayed less severe dehumanization than its Eastern Europe counterpart. However, the distancing methods used by the Nazi administration to protect their perpetrators from psychological trauma provide a tentative explanation as to why Western Europe received a low severity of dehumanization score. Consequently, the demonstrated relationship 
between social proximity and severity of dehumanization still stands: the smaller the social distance between the perpetrator and victim groups prior to the outbreak of genocide, the more severe the dehumanization behaviors of the perpetrators during the killing operations of the genocide.

It is acknowledged, that this research is limited in the extent to which it can draw unequivocal conclusions. It is readily admitted that the literature-based nature of such analysis contains restrictions in its ability to render unbiased objective information. However, despite the limitations this type of research may have, it appears that the hypothesis regarding the inverse correlation between social distance and severity of dehumanization during genocide has found corroboration. With this in hand, one is equipped with an adequate platform from which to launch further research and investigation.

The Holocaust and later the Rwandan Genocide introduced the world to humanity's ability to circumvent all moral, ethical and bureaucratic obstacles in a merciless quest to exterminate fellow human beings. But more than this, the Holocaust and the Rwandan Genocide introduced the world to the fundamental role dehumanization plays in genocide and the ways in which its intensity varies and its trajectory is affected.

As long as humanity continues to commit genocide, dehumanization will continue to chaperon it. Consequently, it is our duty as scholars and as members of the human race to understand the dynamics of dehumanizing behavior during genocide, why it occurs, why it varies and what can be done to combat it.

Lisa Haagensen, MSc, is an independent researcher currently residing in Beijing. She completed her Master's thesis at the University of Amsterdam in 2009. Titled "Relative Harm: The Impact of Social Distance on Dehumanization Behaviors during Genocide," it dealt with the relationship between social distance and severity of dehumanization during genocide.

Marnix Croes, PhD, is a scientific researcher with the Scientific Research and Documentation Centre at the Ministry of Safety and Justice in the Netherlands. In 2009, he taught the comparative genocide analysis Master's thesis project at the University of Amsterdam's Department of Political Science.

\section{Notes}

1. Corresponding author. Correspondence to: lisahaag@gmail.com. We would like to thank the editors and the three anonymous reviewers of Genocide Studies and Prevention for their comments to a previous version that helped improve our paper.

2. Helen Fein, Genocide: A Sociological Perspective (London: Sage Publications, 1993), 24.

3. Jacques Depelchin, "The History of Mass Violence since Colonial Times: Trying to Understand the Roots of Mindset," Development Dialogue 5 (2008): 13-32.

4. James Waller, "Perpetrators of Genocide: An Explanatory Model of Extraordinary Human Evil," Journal of Hate Studies 1,1 (2002): 5-22; James Waller, Becoming Evil: How Ordinary People Commit Genocide and Mass Killing (Oxford: Oxford UP, 2002).

5. Waller, "Perpetrators of Genocide," 5-22.

6. Alexander Alvarez, "Adjusting to Genocide: The Techniques of Neutralization and the Holocaust," Social Science History 21,2 (1997): 139-78; Helen M. Hintjens, "Explaining the 1994 Genocide in Rwanda," Journal of Modern Africa Studies 37,2 (1999): 241-86.

7. Jean Hatzfeld, Life Laid Bare: The Survivors in Rwanda Speak (New York: Other, 2000), 81.

8. Ibid., 75,81 .

9. Hatzfeld, Life Laid Bare; Jean Hatzfeld, A Time for Machetes: The Rwandan Genocide; The Killers Speak (New York: Farrar, Straus and Giroux, 2003).

10. Hatzfeld, Life Laid Bare, 81.

11. The 1935 Law for the Protection of German Blood and Honor defined the term Jew as "persons descended from two Jewish grandparents belonging to the Jewish religion or married to a Jewish person on September 15, 1935 and persons descended from three or four Jewish grandparents." Raul Hilberg, The Destruction of the European Jews (New York: Holmes and Meier, 1985), 80. 
12. Hatzfeld, A Time for Machetes, 60.

13. Debra A. Komar, "Variables Influencing Victim Selection in Genocide," Journal of Forensic Sciences 53,1 (2008): 172.

14. “Convenant Kleurrijke Basisscholen" [Agreement regarding mixed primary schools], 28 June 2007, www.gemengdescholen.eu/View.aspx?id=332 (accessed 16 Oct 2011).

15. Roy F. Baumeister, Evil: Inside Human Violence and Cruelty (New York: Henry Holt, 1999), 206.

16. Herbert C. Kelman, "Violence Without Moral Restraint: Reflections on the Dehumanization of Victims and Victimizers," Journal of Social Issues 29 (1973): 25-61.

17. David Moshman, "Us and Them: Identity and Genocide," Identity: An International Journal of Theory and Research 7,2 (2007): 115-35.

18. Rowan Savage, "Disease Incarnate: Biopolitical Discourse and Genocidal Dehumanization in the Age of Modernity," Journal of Historical Sociology 20,3 (2007): 404-40; Michael R. Hulsizer and Linda M. Woolf, "Psychological Roots of Genocide: Risk, Prevention, and Intervention," Journal of Genocide Research 7,1 (2005): 101-28; Albert Bandura, "Selective Activation and Disengagement of Moral Control," Journal of Social Issues 46,1 (1990): 27-48.

19. Moshman, "Us and Them," 115-35; Michelle Maiese, "Dehumanization" in Beyond Intractability, ed. Guy Burgess \& Heidi Burgess, Conflict Research Consortium, University of Colorado-Boulder, July 2003, http://www.beyondintractability.org/bi-essay/dehumanization (accessed 16 Oct 2011).

20. Jennifer L. Eberhardt et al., "Not Yet Human: Implicit Knowledge, Historical Dehumanization, and Contemporary Consequences," Journal of Personality and Social Psychology 94,2 (2008): 293.

21. Nick Haslam, "Dehumanization: An Integrative Review," Personality and Social Psychology Review 10,3 (2006): 252-64.

22. Albert Bandura, Bill Underwood, and Micheal E. Fromson, "Disinhibition of Aggression through Diffusion of Responsibility and Dehumanization of Victims," Journal of Research in Personality 9,4 (1975): 253-69; Vahakn N. Dadrian, "Patterns of Twentieth Century Genocides: The Armenian, Jewish and Rwandan Cases," Journal of Genocide Research 6,4 (2004): 487-522; Hulsizer and Woolf, "Psychological Roots," 101-28; Moshman, "Us and Them," 115-35; Savage, "Disease Incarnate," 404-40.

23. Haslam, "Dehumanization," 252-64.

24. Moshman, "Us and Them," 122.

25. Kelman, "Violence Without Moral Restraint," 25-61.; Ervin Staub, "The Psychology of Perpetrators and Bystanders," Political Psychology 6,1 (1985): 61-85.

26. Savage, "Disease Incarnate," 404-40.

27. Avishai Margalit and Gabriel Motzkin, "The Uniqueness of the Holocaust," Philosophy and Public Affairs 25,1 (1996): 71.

28. Margalit and Motzkin, "Uniqueness of the Holocaust," 65-83; Moshman, "Us and Them," 115-35; Kelman, "Violence Without Moral Restraint," 25-61.

29. Baumeister, Evil, 331.

30. Christopher C. Taylor, "A Gendered Genocide: Tutsi Women and Hutu Extremists in the 1994 Rwanda Genocide," PoLAR: Political and Legal Anthropology Review 22,1 (2008): 42-54, 179.

31. John F. Galliher and Colin Wark, "Emory Bogardus and the Origins of the Social Distance Scale," American Sociologist 38,4 (2007): 392.

32. Galliher and Wark, "Origins of the Social Distance Scale," 383-95.

33. Daniel J. Cover, "The Effect of Social Contact on Prejudice," Journal of Social Psychology 135,3 (1995): 403.

34. Cover, "Effect of Social Contact," 403.

35. Ehor O. Boyanowsky, Michael H. Bond and Donald G. Dutton, "Extreme Mass Homicide: From Military Massacre to Genocide," Aggression and Violent Behavior 10,4 (2005): 437-73; Hintjens, "Explaining the 1994 Genocide in Rwanda," 241-86.

36. Erin K. Baines, "Body Politics and the Rwandan Crisis," Third World Quarterly 24,3 (2003): 479-93; Charles Mironko, "Igitero: Means and Motive in the Rwandan Genocide," Journal of Genocide Research 6,1 (2004): 55-6.

37. Scott Straus, The Order of Genocide: Race, Power and War in Rwanda (New York: Cornell UP, 2006), 127.

38. Ibid., 129.

39. Hatzfeld, Time for Machetes, 113; Hatzfeld, Life Laid Bare, 81; Baines, "Body Politics," 479-93.

40. Baines, "Body Politics," 479-93; Boyanowsky, Bond, and Dutton, "Extreme Mass Homicide," 241-86; Hintjens, "Explaining the 1994 Genocide in Rwanda," 241-86; Jean Mukimbiri, "The Seven Stages of the Rwandan Genocide," Journal of International Criminal Justice 2,4 (2005): 823-36; Taylor, 
"Gendered Genocide," 42-54; Stefan Woolf, Ethnic Conflict: A Global Perspective (New York: Oxford UP, 2006); Mironko, "Igitero," 47-60.

41. Hintjens, "Explaining the 1994 Genocide in Rwanda," 241-86; Taylor, "Gendered Genocide," 42-54.

42. Mahmood Mamdani, When Victims Become Killers: Colonialism, Nativism and the Genocide in Rwanda (New Jersey: Princeton UP, 2001), 4.

43. Baines, "Body Politics," 479-93; Hatzfeld, Life Laid Bare; Mamdani, When Victims Become Killers.

44. Mamdani, When Victims Become Killers, 4.

45. Hatzfeld, Life Laid Bare; Hatzfeld, Time for Machetes; Mironko, "Igitero," 47-60.

46. Hatzfeld, Time for Machetes, 91.

47. Ibid., 91-3.

48. Hatzfeld, Life Laid Bare, 54.

49. Mironko, "Igitero," 47-60.

50. Ibid.

51. Andrew Storey, "Economics and Ethnic Conflict: Structural Adjustment in Rwanda," Development Policy Review 17,1 (2002): 43-63.

52. Storey, "Economics and Ethnic Conflict," 43-63.

53. Philip Verwimp, "Development Ideology, the Peasantry and Genocide: Rwanda Represented in Habyarimana's Speeches," Journal of Genocide Research 2,3 (2002): 332-3.

54. Julius Adekunle, Culture and Customs of Rwanda (Westport, CT: Greenwood, 2007).

55. Adekunle, Culture and Customs of Rwanda, 11; Hatzfeld, Life Laid Bare, 40, 46.

56. Storey, "Economics and Ethnic Conflict," 53.

57. Woolf, "Psychological Roots," 101-28.

58. Straus, Order of Genocide, 66-87.

59. Hatzfeld, Life Laid Bare, 99.

60. Ibid., 58.

61. Luke Fletcher, "Turning Interahamwe: Individual and Community Choices in the Rwandan Genocide," Journal of Genocide and Research 9,1 (2007): 25-48.

62. "Supplement B: The Jews of Germany; Census of 1925," in American Jewish Yearbook, ed, H. Schneidemann, vol. 32, 1930-1931 (Philadelphia: Jewish Publication Society of America, 1930), 252-7.

63. Steven M. Lowenstein, "Jewish Intermarriage and Conversion in Germany and Austria," Modern Judaism 25,1 (2005): 25.

64. Nathan Stoltzfus, Resistance of the Heart: Intermarriage and the Rosenstrasse Protest in Nazi Germany (Piscataway, NJ: Rutgers UP, 2001), xxvi.

65. Beate Meyer, Die Verfolgung und Ermordung der Hamburger Juden 1933-1945: Geschichte, Zeugnis, Erinnerung [The persecution and murder of the Jews of Hamburg 1933-1945: History, testimony, memory] (Göttingen: Wallstein Verlag, 2006), 80.

66. Hilberg, Destruction of the European Jews.

67. Ibid., 159.

68. Ibid., 166.

69. Ibid., 168 .

70. Institute of Jewish Affairs, Hitler's Ten-Year War on the Jews (New York: International, 1943$), 6$.

71. Institute of Jewish Affairs, Hitler's Ten-Year War.

72. Ibid.

73. Hilberg, Destruction of the European Jews; Institute of Jewish Affairs, Hitler's Ten-Year War.

74. Hilberg, Destruction of the European Jews, 157-8.

75. Ibid., 171.

76. Institute of Jewish Affairs, Hitler's Ten-Year War, 9.

77. Ina Friedman, Hayah Galai, and Leni Yahil, The Holocaust: The Fate of the European Jewry, 1932-1945 (New York: Oxford UP, 1990).

78. Raul Hilberg (b), The Destruction of the European Jews (Chicago: Quadrangle Books, 1961), 62.

79. Lisa Pine, Nazi Family Policy, 1933-1945 (Oxford: Berg, 1991), 150.

80. Stoltzfus, Resistance of the Heart, 98.

81. Ibid.

82. Ibid., xxix.

83. Wolf Gruner, "The Factory Action and the Events at the Rosenstrasse in Berlin: Facts and Fictions about 27 February 1943; Sixty Years Later," Central European History 36,2 (2003): 179-208.

84. Gruner, "Events at the Rosenstrasse," 179-208.

85. Stoltzfus, Resistance of the Heart, 248.

86. Lowenstein, "Jewish Intermarriage," 23-61. 
87. Hilberg (b), Destruction of the European Jews.

88. Ibid.

89. Relying on human observers means that researchers have to worry about the reliability of the data. Are these data the result of human idiosyncracies or do they reflect properties of the phenomena of interest on which others could agree as well? To test for this, we used Krippendorf alpha (see Andrew F. Hayes \& Klaus Krippendorf, "Answering the Call for a Standard Reliability Measure for Coding Data," Communication Methods and Measures 1,1 [2007]: 77-89) and the SPSS syntax Hayes and Krippendorff have made availabe (Andrew F. Hayes, "My Macros and Code for SPSS and SAS," http://www.afhayes. com/spss-sas-and-mplus-macros-and-code.html [accessed 16 Oct 2011]). A still acceptable level of agreement between our respondents to draw conclusion meant that Krippendorffs alpha had to be at least 0.67 (see Klaus Krippendorff, "Reliability in Content Analysis: Some Common Misconceptions and Recommendations," Human Communication Research 30,3 [2004]: 411-433). However, using Krippendorffs estimation procedure resulted in an alpha of 0.66 (with 10,000 bootstrap samples and $\mathrm{p}<0.71$ that alpha would be smaller than 0.67 ). We therefore opted to omit behavior 4 (see table 9) from our analysis because the standard deviation of the scores given by the respondents was the highest for this type of behavior while omitting it did not influence the results reported here in a fundamental way. Doing so resulted in an alpha of 0.70 (with 10,000 bootstrap samples and $p<0.05$ that alpha would be smaller than 0.67). We therefore conclude that there is an acceptable level of agreement between our respondents.

90. Bandura, "Selective Activation," 38.

91. Hulsizer and Woolf, "Psychological Roots," 101-28; Moshman, "Us and Them," 115-35.

92. Emanuele Castano and Roger Giner-Sorolla, "Not Quite Human: Infrahumanization in Response to Collective Responsibility for Intergroup Killing," Journal of Personality and Social Psychology 90,5 (2006): 804-18; Bandura, "Selective Activation," 38-9.

93. "SS Commandant Franz Stangl," The Holocaust Website, http://www.auschwitz.dk/sobibor/franzstangl. htm (accessed 16 Oct 2011).

94. Bandura, "Selective Activation," 38.

95. Hatzfeld, Life Laid Bare, 81.

96. Ibid., 83.

97. Willi Dressen, Ernst Klee, and Volke Riess, "The Good Old Days": The Holocaust as Seen by its Perpetrators and Bystanders (Old Saybrook, CT: Konecky \& Konecky, 1991), 96.

98. Konrad Kwiet, "Rehearsing for Murder: The Beginning of the Final Solution in Lithuania in June 1941," Holocaust and Genocide Studies 12,1 (1998): 4.

99. Hilberg (b), The Destruction of the European Jews, 205.

100. Dov Levin, "On the Relations Between the Baltic Peoples and their Jewish Neighbors Before, During and After World War II," Holocaust and Genocide Studies 5,1 (1990): 56.

101. Ibid.

102. Kwiet, "Rehearsing for Murder," 4.

103. Max Kaufmann, Churbn Lettland: The Destruction of the Jews of Latvia, trans. Laimdota Mazzarins (Max Kaufmann: Munich,1947), 32, http://www.jewsoflatvia.com/thebook.html (accessed 16 Oct 2011).

104. Kaufmann, Churbn Lettland, 90.

105. Kwiet, "Rehearsing for Murder," 4.

106. Hilberg (b), Destruction of the European Jews, 205.

107. Levin, "Relations Between the Baltic Peoples," 56.

108. "The Untold Stories: The Murder Sites of the Jews in the Occupied Territories of the former USSR: Written Testimonies," Yad Vashem, http://wwwl.yadvashem.org/untoldstories/database/writtenTestimonies. asp? cid=384\&site_id $=489$ (accessed 16 Oct 2011).

109. Levin, "Relations Between the Baltic Peoples," 56.

110. "A Simulation Study of the Psychology of Imprisonment Conducted at Stanford University," Stanford Prison Experiment, http://www.prisonexp.org (accessed 16 Oct 2011).

111. Ibid.

112. "Setting Up: Selecting Participants," The BBC Prison Study, BBC, http://www.bbcprisonstudy.org/ bbc-prison-study.php?p=21 (accessed 16 Oct 2011).

113. Ibid..

114. Hilberg (b), The Destruction of the European Jews, 646; Margalit and Motzkin, "Uniqueness of the Holocaust," 65-83.

115. Hilberg (b), The Destruction of the European Jews, 646.

116. Ibid., 648. 
117. Ibid.

118. Ibid.

119. Rudolf Höss, Death Dealer: The Memoirs of the SS Kommandant at Auschwitz (New York: Da Capo, 1992), 157.

120. Ibid.

121. Christopher R. Browning, Ordinary men: Reserve Battalion 101 and the Final Solution (New York: Harper Perennial, 1993).

122. Höss, Death Dealer, 157.

123. Hilberg (b), Destruction of the European Jews, 648.

124. Höss, Death Dealer, 28.

125. Ibid., 157.

126. Ibid., 157-8.

127. Hilberg (b), Destruction of the European Jews, 648. 